\title{
Upaya Indonesia Meningkatkan Pariwisata Maritim melalui Diplomasi Kebudayaan di Asia Tenggara
}

\author{
Harits Dwi W. \\ Bagus Subekti N. \\ Universitas Respati Yogyakarta
}

\begin{abstract}
Indonesia is one of the largest archipelagic countries in the world, having more than 17,000 islands. It becomes one priority to the state building, more importantly in the national economy. State economic development can be driven by maximizing the potential of seawater through the tourism industry, especially in maritime tourism which is one part of the third pillars of the maritime axis. Maritime tourism may serve as an instrument of Indonesian diplomacy to compete in Southeast Asia's tourism race. It could be very significant when the government is able to manage the potential resources. This paper argues that maritime tourism is potential for Indonesian development through maritime tourism industry in the future. This paper employs cultural diplomacy concept to describe how cultural diplomacy plays role as an instrument in promoting Indonesia's tourism industry in the region.
\end{abstract}

Keywords: maritime tourism, cultural diplomacy, tourism industry

\begin{abstract}
Abstrak
Indonesia merupakan salah satu negara kepulauan terbesar di dunia yang memiliki lebih dari 17.000 pulau. Kondisi ini dapat menjadi prioritas bagi negara dalam membangun perekenomian suatu bangsa. Pembangunan ekonomi negara dapat dilakukan dengan memaksimalkan potensi laut melalui industri pariwisata, khususnya pariwisata maritim yang merupakan salah satu bagian dari pilar ketiga poros maritim. Pariwisata maritim dapat dijadikan sebagai instrumen diplomasi oleh Indonesia untuk bersaing secara kompetitif dalam bidang pariwisata di kawasan regional Asia Tenggara. Kondisi ini sangat signifikan apabila dilakukan dengan tepat dan serius oleh pemerintah. Tulisan ini berargumen bahwa pariwisata maritim memiliki potensi yang cukup besar bagi pembangunan Indonesia, melalui industri pariwisata maritim di masa depan. Tulisan ini menggunakan konsep diplomasi kebudayaan untuk menggambarkan bagaimana diplomasi kebudayaan berperan sebagai instrumen dalam mempromosikan industri pariwisata Indonesia di kawasan regional.
\end{abstract}

Kata-kata kunci: pariwisata maritim, diplomasi kebudayaan, industri pariwisata 


\section{Pendahuluan}

Indonesia merupakan salah satu negara yang memiliki wilayah sangat luas dari Pulau Sabang sampai Merauke dan termasuk negara kepulauan yang mempunyai lebih dari 17.000 pulau. Kondisi tersebut merupakan daya tarik tersendiri bagi wisatawan asing maupun lokal. Hal ini menjadikan Indonesia salah satu negara tujuan wisatawan di Asia Tenggara. Kekayaan alam yang dimiliki oleh Indonesia menjadi potensi di masa sekarang ataupun di masa yang akan datang. Potensi ini dapat dilihat dari keindahan pulau yang terbentang dari ujung barat hingga ujung timur. Keindahan alam menjadi salah satu keunggulan khususnya wisata bahari Indonesia memiliki garis pantai terpanjang di dunia. Keadaan tersebut memiliki ruang bagi seluruh stakeholder yang ada di Indonesia untuk mengupayakan nilai tambah (creating values) dalam industri pariwisata.

Meningkatkan kualitas dalam industri pariwisata menjadi salah satu tantangan bagi pemerintah, swasta ataupun masyarakat di Indonesia. Hal ini dapat dilihat dari ranking Indonesia di Asia Tenggara yang menempati urutan ke-4 (world economic forum, 2016). Peringkat Indonesia masih kalah bersaing dengan Singapura, Thailand dan Malaysia. Meskipun ditinjau dari segi luas wilayah dan kekayaan alam, Indonesia memiliki berbagai keunggulan dibandingkan dengan Singapura, Thailand maupun Malaysia. Namun kenyataannya Indonesia masih menempati posisi di bawah negara-negara tersebut. Hal ini menjadi perhatian khusus bagi pemerintah untuk lebih serius lagi dalam mengelola kekayaan alam yang ada di Indonesia serta lebih cerdik dalam mempromosikan pariwisata Indonesia melalui diplomasi kebudayaan.

Indonesia memiliki UU No.10 Tahun 2009 Tentang Kepariwisataan, dengan ini pemerintah memiliki amanah untuk menerapkan kebijakan terkait pembangunan industri pariwisata. Di lain pihak, Indonesia memiliki keunggulan dari negara lain jika dilihat sebagai comparative advantage. Beberapa contoh Objek Daerah Tujuan Wisata (ODTW) yang sering dikunjungi turis lokal maupun internasional yaitu Bali, Lombok, Bunaken ataupun Raja Ampat. Daerah tersebut merupakan salah satu tempat favorit bagi para wisatawan yang datang ke Indonesia. Hal ini harus menjadi prioritas bangsa Indonesiayang sebagian besar negara ini adalah lautan. Lautan yang potensial mempertegas posisi wisata bahari (marine tourism) sebagai salah satu pariwisata berkualitas yang harus dikembangkan selain Eco Tourism, Adventure, Heritage, Religi dan Wisata Ziarah, Art dan Culinary Tourism, dan lain-lain (Kementrian Pariwisata RI, 2015). Dilihat dari aspek pembangunan ekonomi sangat menjanjikan apabila industri pariwisata bahari dapat dijadikan sebagai aset di masa yang akan datang.

Indonesia memiliki kepentingan yang besar dalam meningkatkan perekonomian negara. Potensi kelautan yang sangat kaya, telah menem- 
patkan posisi pariwisata maritim (bahari) sebagai salah satu pionir utama dalam mencapai tujuan ekonomi Indonesia. Dengan menjadikan objek pariwisata sebagai atmosfir bagi kedatangan turis-turis dunia khususnya ASEAN, pariwisata telah menjadi contoh nyata bagi Indonesia dalam menjalankan diplomasi kebudayaan. Kepentingan nasional Indonesia untuk meningkatkan perekonomian berusaha dijawab dengan menerapkan diplomasi kebudayaan. Penerapan diplomasi kebudayaan ini melalui promosi pariwisata bahari ke luar negeri khususnya wilayah ASEAN sebagai poin ketiga dalam poros maritim yang juga merupakan unggulan utama pariwisata berkualitas di Indonesia. Namun pemerintah masih memiliki pekerjaan rumah terkait dengan upaya untuk meningkatkan pariwisata tersebut. Sehingga dari sini penulis ingin menjawab pertanyaan tentang "Bagaimana upaya pemerintah Indonesia dalam meningkatkan pariwisata maritim (pilar ketiga poros maritim) melalui diplomasi kebudayaan di kawasan Asia Tenggara?"

\section{Kerangka Konseptual: Diplomasi Kebudayaan}

Riset ini menggunakan konsep diplomasi kebudayaan guna memahami tujuan dari kepentingan nasional Indonesia dalam mengembangkan sektor perekonomian khususnya dalam bidang pariwisata maritim. Kebudayaan adalah satu dari tiga sumber kemampuan soft power (kebudayaan, nilai-nilai politik dan kebijakan luar negerinya). Sebagaimana dijelaskan oleh Joseph Nye dalam bukunya Soft Power : The Means to Success in World Politics, soft power diartikan sebagai kemampuan untuk menciptakan pilihan-pilihan bagi orang lain, yaitu kemampuan untuk memikat pihak lain agar rela memilih melakukan suatu hal yang dikehendaki tanpa perlu untuk memintanya (Nye, 2004). Joseph Nye melihat potensi yang besar dari budaya pada era ini sebagai satu kekuatan yang krusial dalam memberikan daya tarik tersendiri bagi bangsa lain. Daya tarik tersebut dapat memperkuat hubungan kerjasama antar negara demi mencapai kepentingan nasionalnya terutama dalam bidang ekonomi.

Pada abad modern diplomasi menjadi metode yang dipilih oleh suatu negara untuk mencapai tujuan-tujuannya secara damai (Roy, 1995:4). Dalam perkembangan dunia dewasa ini, soft power telah menjadi sesuatu yang penting, karena Soft power diplomacy yang berwujud culture, ideas, values, policies ataupun achievement itu, sering kali membuat formula diplomasi menjadi semakin kuat dan menjadi wujud lain dari apa yang dilakukan pada tingkat formal (Yudoyono, 2010). Hal ini diperkuat oleh J.W. Fulbright dalam buku S.L Roy yang berjudul Diplomasi, yang berpendapat bahwa dunia setelah ini akan lebih dipengaruhi oleh seberapa baik suatu negara dalam mengkomunikasikan nilai-nilai kebudayaan masyarakatnya kepada negara lain (Roy, 1995:12). Mengingat perang sudah bu- 
kan lagi menjadi instrumen pilihan untuk mencapai kepentingan nasional suatu negara maka diplomasi kebudayaan menjadi satu alternatif bagi setiap negara seperti Indonesia dalam mencapai kepentingan nasionalnya.

Kebudayaan merupakan hasil dari upaya budi daya yang dilakukan manusia. Dengan kreatifitasnya manusia berusaha menjadikan satu hal yang biasa menjadi lebih unik dan memiliki nilai. Dalam hal ini Indonesia berupaya mengolah pariwisata maritim sedemikian rupa agar dapat menjadi suatu yang menarik serta memiliki nilai seni dan kebudayaan di mata dunia khsusnya kawasan ASEAN. Perhatian dunia terhadap kebudayaan Indonesia memberikan keuntungan tersendiri karena dapat menaikkan posisi tawar (bargaining position) di dalam hubungan internasional. Usaha Indonesia untuk memperjuangkan kepentingan nasionalnya melalui dimensi kebudayaan inilah yang oleh Tulus Warsito dan Wahyuni Kartikasari sebut sebagai diplomasi kebudayaan. Adapun tujuannya adalah untuk mempengaruhi pendapat umum (negara lain) guna mendukung suatu kebijaksanaan politik luar negeri tertentu (Warsito, 2007). Beginilah cara Indonesia berusaha menyampaikan kebudayaannya melalui pariwisata.

Pariwisata memberikan sumbangan yang signifikan dalam meningkatkan perekonomian suatu negara. Selain itu pariwisata juga turut dalam memajukan kebudayaan. Pariwisata itu sendiri mengandung kegiatan-kegiatan kebudayaan sebagaimana tercantum dalam Undang-Undang Republik Indonesia Nomor 10 Tahun 2009, yang mendefinisikan pariwisata sebagai beberapa macam kegiatan wisata dan didukung berbagai fasilitas serta layanan yang disediakan oleh masyarakat, pengusaha, pemerintah, dan pemerintah daerah(UUD, 2009). Melalui pariwisata, masyarakat domestik dan internasional dapat mengenal lebih dalam kebudayaan yang ada di Indonesia, sehingga menjadi modal yang baik dalam meningkatkan kekuatan diplomasi kebudayaan di Indonesia. Di sisi lain pariwisata merupakan kegiatan yang berkenaan dengan usaha memenuhi kebutuhan hidup manusia untuk memperoleh kesenangan. Kesenangan itu dinikmati berkat adanya jasa yang diberikan oleh pihak tertentu (Hakim, 2010). Dari jasa tersebut Indonesia dapat menunjukkan karakteristik serta nilai dari kebudayaannya dan menjadi bahan utama diplomasi kebudayaan untuk mencapai pertumbuhan ekonomi negara.

Pariwisata itu sendiri adalah suatu industri. Sesuai dengan istilahnya, pengertian industri adalah The quality of working hard, the production of goods, the creation of wealth by human efforts (Hakim, 2010). Industri pariwisata merupakan stakeholder pariwisata yang berupaya menciptakan pertumbuhan perekonomian, menciptakan lapangan kerja, serta menghapus kemiskinan terhadap masyarakat di sekitar destinasi pariwisata (Yahya, 2015). Sejak awal tahun 90-an sektor pariwisata sudah menjadi sumber devisa terbesar keenam sesudah minyak bumi, gas, kayu, tekstil 
dan karet (Mas'ud, 2008). Hal ini mempertegas posisi pariwisata dalam pengembangan perekonomian negara. Undang-Undang Republik Indonesia Nomor 10 Tahun 2009 mendefinisikan Industri pariwisata sebagai kumpulan usaha pariwisata yang saling terkait dalam rangka menghasilkan barang dan/atau jasa bagi pemenuhan kebutuhan wisatawan dalam penyelenggaraan pariwisata. Usaha untuk menghasilkan barang dan jasa dapat dilakukan oleh pemerintah ataupun masyarakat sekitar. Sehingga semakin banyak masyarakat yang berperan dalam penyelenggaraan pariwisata, menjadi indikator pertumbuhan perekonomian di daerah tersebut.

\section{Upaya Indonesia dalam Meningkatkan Pariwisata Maritim}

Industri pariwisata pada saat ini menjadi salah satu unggulan bagi negara-negara maju maupun negara berkembang. Hal ini dapat dilihat dari jumlah pendapatan dunia dari sektor pariwisata. Jumlah wisatawan internasional di seluruh dunia, pada 2015, naik 4,4\% atau menyentuh angka 1,18 miliar, kendati ada kekhawatiran atas aksi terorisme yang terjadi di beberapa bagian belahan dunia. Dari jumlah yang sangat signifikan memberikan peluang bagi beberapa negara yang memiliki potensi dalam industri pariwisata. John Naisbitt meramalkan bahwa dalam globalisasi, pariwisata merupakan industri terbesar di dunia (Gel, 2006). Kondisi tersebut dapat memancing negara-negara maju maupun berkembang untuk meningkatkan industri pariwisatanya. Sehingga peluang tersebut dapat diambil untuk meningkatkan penerimaan devisa negara dari sektor industri pariwisata.

Kontribusi dari sektor pariwisata harus mendapat penanganan yang serius bagi suatu negara. Hal ini dapat dilihat dari pertumbuhan dan peluang sektor pariwisata dunia dalam tahun 2015. Kondisi tersebut dapat dilihat dari laporan dari UNWTO (United Nation World Tourism Organization), (Happy, 2016) yaitu: kedatangan wisatawan internasional tumbuh sebesar 4,6\% pada tahun $2015 \mathrm{ke} \mathrm{1,184} \mathrm{M} \mathrm{sedangkan} \mathrm{pariwisata} \mathrm{internasion-}$ al yang menghasilkan US \$ 1,5 triliun pendapatan ekspor; UNWTO memperkirakan pertumbuhan kedatangan wisatawan internasional antara 3,5\% dan $4,5 \%$ pada tahun 2016; dan pada tahun 2030, UNWTO memperkirakan kedatangan wisatawan internasional akan mencapai 1,8 miliar (Pariwisata UNWTO Menuju 2030, 2015).

Perkembangan industri pariwisata telah mengalami pertumbuhan yang sangat signifikan di dunia. Sektor pariwisata dapat mendorong kemajuan dalam bidang ekonomi suatu negara. Salah satu cara yang dapat dilakukan untuk mendorong sektor pariwisata adalah diplomasi kebudayaan. Diplomasi dalam konteks industri pariwisata dapat melalui diplomasi kebudayaaan. Diplomasi kebudayan menjadi salah satu instrumen 
untuk mencapai sebuah kepentingan suatu bangsa. Indonesia merupakan salah satu negara yang memiliki keunggulan dari sektor pariwisata khususnya dalam hasil sumber daya alamnya (natural resources).Sebagaimana kita ketahui, saat ini wisata bahari menjadi salah satu industri terbesar di dunia dan menjadi sektor ekonomi yang berkembang sangat pesat (WWF, 2015). Indonesia mendapatkan keuntungan dari luas wilayah yang sangat strategis. Wilayah Indonesia sebagian besar dikelilingi oleh lautan sehingga memiliki potensi wisata yang dapat menjadi daerah unggulan wisatawan mancanegara maupun domestik. Menjadi negara maritim artinya memiliki kapasitas untuk memanfaatkan laut sebagai ruang hidup (lebensraum) untuk kepentingan nasional (Rahmawaty, 2015). Oleh karena itu, momentum ini menjadi salah satu upaya yang dilakukan Indonesia dalam meningkatkan pariwisata maritim sebagai pilar ketiga poros maritim melalui diplomasi kebudayaan khususnya di kawasan Asia Tenggara.

Meningkatkan Kerja Sama Industri Pariwisata di Tingkat Regional Asia Tenggara

Industri pariwisata merupakan salah satu aktifitas yang memiliki potensi di masa yang akan datang. Di kawasan Asia Tenggara dalam beberapa tahun terakhir mengalami peningkatan dari sisi pemasukan sektor pariwisata. Di sisi lain, Indonesia berada di peringkat 4 dibawah Thailand, Malaysia dan Singapura dalam hal pendapatan dari sektor pariwisata. Oleh karena itu, upaya yang dapat dilakukan oleh Indonesia dengan cara meningkatkan kerja sama dengan bilateral ataupun multilateral dengan negara-negara di kawasan Asia Tenggara. Apabila melihat potensi sumber daya alam dan jumlah penduduk Indonesia kerja sama dengan beberapa negara dapat saling menguntungkan. Di lain pihak, kerja sama tersebut bisa dilakukan dengan beberapa pihak swasta yang memiliki ketertarikan dalam industri parwisata.

Dalam forum resmi yang telah dibentuk oleh komunitas negara-negara ASEAN berkaitan dengan sektor pariwisata yaitu ASEAN Tourism Forum (ATF). Forum regional ASEAN tersebut dapat digunakan sebagai cara untuk mempromosikan Indonesia di tingkat regional. Di sisi lain, Indonesia sampai saat ini masih tertinggal dari beberapa negara pesaing. Thailand, Singapura dan Malaysia memiliki peringkat lebih baik dibanding dengan Indonesia. Forum-forum ini dapat menjadi salah satu nilai tambah bagi bangsa ini untuk mengelola industri pariwisatanya dengan lebih baik. Pendekatan yang digunakan oleh bangsa ini dengan cara pendekatan diplomasi budaya. Pendekatan ini dapat dijadikan sebagai instrumen dalam mencapai kepentingan nasional.

ATF merupakan sebuah forum yang sangat penting untuk dipertahankan di masa yang akan datang. forum atau aktifitas yang bersifat non 
politik dari suatu negara dapat memberikan dampak terhadap kemajuan pembangunan suatu bangsa. Forum yang berdiri sejak tahun 1981 di Malaysia menjadi salah satu pendorong yang utama bagi pembangunan pariwisata di kawasan ASEAN. Hal ini dapat dilihat dari tujuan pendirian ATF (ATF, 2009) yaitu: proyek ASEAN sebagai hal yang menarik, berbagai hal satu tujuan; menciptakan dan meningkatkan kesadaran ASEAN sebagai daerah tujuan wisata yang sangat kompetitif di Asia Pasifik; menarik lebih banyak turis dari negara-negara anggota ASEAN; mempromosikan wisatawan antar negara ASEAN; dan memperkuat kerja sama antara berbagai sektor industri pariwisata ASEAN.

Forum ATF menjadi salah satu wadah investasi Indonesia di tingkat regional melalui sektor pariwisata. Sektor ini dalam beberapa dekade memiliki tingkat pertumbuhan di setiap negara bahkan tingkat kawasan. Aktifitas wisata dapat dikatakan sebuah kebutuhan bagi setiap individu bahkan kelompok tertentu. Dalam kajian hubungan internasional isu ini menjadi salah satu gambaran bahwa pariwisata menjadi salah satu fenomena. Perkembangan secara global maupun regional dari segi pembangunan dapat memberikan dampak terhadap perekonomian masyarakat suatu negara.

\section{Mendirikan Pusat Studi Indonesia di Universitas Asia Tenggara}

Agenda kerja sama dalam bidang pariwisata dapat dilakukan dengan secara bilateral maupun multilateral. Pada saat ini dalam era globalisasi dibutuhkan kerja sama untuk saling menguntungkan. Kerja sama antar negara menjadi bagian yang tidak dapat dipisahkan dari aktifitas diplomasi. Diplomasi bilateral dan multilateral mempunyai dampak bagi pembangunan ekonomi suatu bangsa khususnya dalam bidang pariwisata. Hubungan ini dapat diimplementasikan melalui pendirian beberapa Pusat Studi Indonesia di Universitas yang ada di Asia Tenggara atau Indonesian Corner. Pendirian pusat studi ini di masa yang akan datang dapat memberi dampak bagi bangsa Indonesia. Hal tersebut menjadi sebuah dorongan yang positif untuk menggerakkan berbagai sektor yang ada di Indonesia khususnya bidang industri pariwisata. Negara-negara yang berada di kawasan Asia Tenggara menjadi peluang bagi bangsa Indonesia untuk melakukan tindakan yang konkrit dalam bidang budaya.

Adanya Pusat Studi Indonesia atau Indonesian Corner merupakan sebuah aset negara. Hal ini dapat membantu masyarakat Asia Tenggara untuk mengenal Indonesia lebih mendalam. Pendirian pusat studi yang ada di berbagai universitas di Indonesia memiliki dampak yang positif bagi masyarakat kampus. Civitas kampus dapat mempelajari bahasa, budaya, sosial dan politik negara tersebut. Universitas mempunyai posisi yang 
penting dalam percaturan diplomasi budaya antar negara di regional Asia Tenggara. Indonesia perlu menyiapkan strategi dalam menghadapi Masyarakat Ekonomi ASEAN (MEA) khususnya dalam bidang budaya.

\section{Mendirikan Kantor Promosi Wisata di Kawasan Asia Tenggara}

Pada saat ini perkembangan dunia pariwisata menjadi salah satu aspek yang penting dalam hal perolehan dari devisa negara. Oleh karena itu membutuhkan suatu upaya untuk menarik wisatawan mancanegara. Kondisi tersebut dapat dilakukan oleh negara dengan cara mendirikan kantor promosi pariwisata di luar negeri. Pendirian kantor di luar negeri memberikan sebuah peluang untuk lebih dekat dengan masyarakat asing, sehingga akan lebih mudah untuk mengenalkan berbagai macam potensi lokal yang dimiliki oleh Indonesia. Di lain pihak, pendirian ini dapat diartikan sebagai kantor perwakilan khusus dalam bidang industri pariwisata. Di Asia Tenggara dapat kita lihat kemajuan dari negara Thailand, salah satu promosi yang dilakukan membuka kantor khusus penanganan pariwisata dengan total 21 kantor di seluruh dunia.

Kemampuan negara sangat dibutuhkan dari segi pendanaan serta strategi yang akan dilakukan. Tanpa adanya komitmen yang kuat dari pemerintah industri pariwisata kita tidak akan pernah ada terobosan baru dalam menarik perhatian para wisatawan asing. Dukungan dana menjadi sangat penting dalam hal pembiayaan promosi pariwisata. Apabila industri ini dijadikan sebuah aset di masa depan, maka pemerintah wajib untuk meningkatkan anggaran pariwisata dapat ditingkatkan di masa yang akan datang. Anggaran pemerintah dalam industri pariwisata sangat kecil apabila dibandingkan dengan pengeluaran dari Thailand, Singapura atau Malaysia. Upaya ini menjadi sebuah cita-cita bangsa Indonesia untuk mengenalkan industri pariwisata kepada masyarakat internasional khususnya di Asia Tenggara. Dalam hal ini negara memiliki peran dalam membuka jalur diplomasi antar negara. Hubungan politik antar beberapa negara dan kebijakan terhadap warga negara asing yang melakukan perjalanan ke, dari dan dalam negeri. Hal ini sangat penting bagi wisatawan temporer untuk saling memahami (Hall, 1994).

Hubungan bilateral dan multilateral menjadi salah satu modal bagi Indonesia untuk meningkatkan promosi wisata. Dari hasil tersebut dapat menghasilkan sebuah kebijakan bersama. Hasil kerja sama tersebut berupa, diberikan sebuah izin mendirikan kantor promosi pariwisata di negara-negara Asia Tenggara, sehingga dapat mendukung program Masyarakat Ekonomi ASEAN (MEA).

Keunggulan pariwisata maritim Indonesia harus diiringi dengan penyediaan infrastruktur serta aksesibilitas. Kedua hal tersebut memiliki arti yang sangat penting dalam mendukung diplomasi Indonesia bidang 
kebudayaan. Salah satu faktor pendorong peningkatan jumlah kedatangan wisatawan mancanegara ke Indonesia, adalah keindahan alam laut. Wisata maritim yang dimiliki oleh bangsa ini merupakan sebuah hal yang perlu di kelola secara profesional. Untuk mendekatkan pariwisata maritim diperlukan sebuah fasilitas pendukung seperti berbagai jenis kapal wisata khususnya kapal pesiar.

Kapal pesiar ini memiliki daya tampung yang signifikan dalam membawa turis mancanegara. Kapasitas kapal pesiar ini memiliki daya tampung sebanyak 2000 orang, sehingga akan memberi dampak terhadap perekonomian suatu daerah. Akan tetapi permasalahan yang ada di Indonesia saat ini belum tersedianya pelabuhan untuk merapatkan kapal pesiar. Pelabuhan yang tersedia di Indonesia baru ada enam yaitu Belawan, Tanjung Priuk, Tanjung Emas, Tanjung Perak, Tanjung Benoadan Makassar. Apabila melihat situasi dan kondisi yang ada di Indonesia terkait potensi wisata maritim perlu adanya dukungan dari pemerintah. Dukungan yang dapat dilakukan oleh pemerintah yaitu penambahan jumlah pelabuhan bertaraf internasional sehingga mampu disinggahi beberapa kapal pesiar. Hal tersebut merupakan peluang yang sangat signifikan dalam mendatangkan wistawan mancanegara.

Di berbagai daerah yang memiliki potensi wisata maritim seperti Bunaken, Pulau banda, Ambon dan Raja Ampat Papua Barat sampai saat ini belum terdapat pelabuhan khusus untuk kapal pesiar. Pembangunan pelabuhan skala internasional di bagian timur Indonesia memberikan pengaruh terhadap pemasukan dari sisi industri pariwisata. Hal ini dapat dibuktikan dengan daya tampung penumpang kapal pesiar yang mampu membawa sekitar lebih dari 2000 wisatawan asing seluruh dunia. Sektor ini memiliki peluang yang signifikan dalam membantu pemerintah untuk meningkatkan devisa negara. Di sisi lain, pemerintah dapat membangun infrastruktur beberapa bandara di daerah yang memiliki potensi wisata sangat menjanjikan khususnya wisata maritim. Pembangunan bandara diharapkan mampu menampung pesawat yang berskala besar di berbagai pulau yang tersebar di wilayah timur Indonesia.

\section{Pertukaran Budaya}

Pertukaran Budaya merupakan cara lain dari upaya Indonesia dalam meningkatkan kekuatan diplomasi kebudayaannya di bidang pariwisata. Hal ini terwujud dalam program PPAN (Pertukaran Pemuda Antar Negara) yang diselenggarakan oleh Kementerian Pemuda dan Olahraga. Salah satu tujuan program tersebut adalah memberikan kesempatan kepada generasi muda untuk lebih mengenal adat-istiadat, kesenian, dan budaya di negara tujuan, tukar-menukar pengalaman serta melakukan kegiatan bersama di negara lain akan menimbulkan saling pengertian, penghormatan 
dan toleransi di kalangan generasi muda. Generasi muda merupakan delegasi sekaligus sasaran terbaik bagi penyebaran kebudayaan pada tingkat internasional. Hal ini disadari oleh beberapa organisasi internasional dengan membuka peluang pertukaran pelajar ataupun kebudayaan melalui beasiswa dan program orang tua asuh.

Salah satu organisasi yang aktif dalam membuka kesempatan pertukaran pelajar internasional adalah Youth For Understanding (YFU) pada program Intercultural Exchange Programs (YFU, 2016). Organisasi ini telah melihat potensi pada pemuda sebagai delegasi terbaik dalam membawa pesan perdamaian pada dunia internasional melalui pendekatan diplomasi kebudayaan. Dari sini para pemuda Indonesia dapat memperkenalkan kebudayaan sekaligus pariwisata nasional ke tingkat dunia. Program ini tidak hanya memberdayakan para pemuda tetapi juga orang tua asuh yang berada di Negara Indonesia. Dengan menerima para pelajar asing dari negara lain, orang tua asuh memiliki kesempatan yang lebih besar dalam memberikan pengetahuan serta pemahaman tentang kebudayaan yang ada di daerahnya. Sehingga semua pengetahuan yang mereka dapatkan dari orang tua asuh tersebut dapat mereka bawa dan mereka sebarkan di negara asal mereka.

\section{Eksebisi}

Penampilan kebudayaan Indonesia di luar negeri menjadi senjata terakhir diplomasi pada tulisan ini. Penampilan kebudayaan yang ditampilkan secara langsung dapat memberikan kesan yang mendalam bagi para penonton. Mereka dapat menangkap dengan jelas pesan serta nilai yang ingin disampaikan melalui pertunjukan tersebut. Salah satu contoh penampilan yang paling sering ditampilkan adalah seni tari. Bahkan pada suatu acara workshop di rilis oleh Koran Tempo di Bulgaria, beberapa penonton dari negara tersebut menyatakan minatnya untuk mempelajari tari kesenian Indonesia yang dipimpin oleh dosen tari dari Institut Seni Indonesia (ISI) Surakarta, Dwi Rahmani di Universitas Sofia (Tempo, 2015). Hal ini menunjukkan kesuksesan peran budaya sebagai senjata baru diplomasi Indonesia di luar negeri. Dengan begitu minat para warga negara asing yang ingin belajar kesenian ke Indonesia serta mengenalkan segala hal yang berhubungan dengan kebudayaan tersebut semakin tinggi. Hal ini akan berimplikasi dengan pengingkatan kunjungan tempat-tempat pariwisata yang sering menampilkan kekayaan budaya Indonesia.

Selain aktif pada eksibisi, delegasi Indonesia juga aktif dalam mengikuti perlombaan kebudayaan bahkan memenangkan beberapa kategorinya. Pada kompetisi World Championship of Folklore "World Folk 2014" di Bulgaria, 21-31 Agustus 2014 lalu. Diikuti oleh Kelompok Gita Gantari Khatulistiwa (GGK) Jakarta dan Unit Kegiatan Mahasiswa Seni Tari Uni- 
versitas Hassanuddin, Makassar, serta meraih juara pertama dan kedua Golden Grand Prix Orpheus (Tempo, 2015).

\section{Kesimpulan}

Indonesia merupakan salah satu negara kepulauan terbesar di dunia. Sehingga memiliki kekuatan dalam bidang kemaritiman, khususnya dalam bidang pariwisata maritim. Melihat berbagai potensi yang ditawarkan oleh Indonesia melalui lautnya, hal tersebut dapat menjadi peluang besar untuk dapat mendatangkan wisatawan asing dan devisa bagi negara. Di lain pihak pemerintah perlu meningkatkan berbagai upaya diplomasi dengan negara lain. Diplomasi kebudayaan menjadi salah satu instrumen bagi Indonesia untuk melakukan promosi di kawasan Asia Tenggara. Berbagai upaya promosi pariwisata Indonesia di luar negeri perlu diiringi dengan komitmen yang kuat dari pemerintah. Adanya komitmen dari pemerintah akan berdampak kepada penguatan pembangunan di bidang parwisata. Berbagai upaya yang dilakukan di tingkat domestik maupun tingkat regional Asia Tenggara. Adanya promosi di kawasan Asia Tenggara dengan berbagai cara yang ditempuh oleh pemerintah melalui kerja sama industri pariwisata dengan negara anggota ASEAN, mendirikan Pusat Studi Indonesia di universitas yang ada di Asia Tenggara, mendirikan kantor promosi wisata di kawasan Asia Tenggara, pertukaran budaya ataupun melakukan Eksebisi. Untuk mendukung adanya diplomasi kebudayaan di kawasan Asia Tenggara diperlukan pembenahan dan pembangunan di dalam negeri, seperti bidang infrastruktur dan aksesibilitas. Kedua bidang ini sangat membantu menarik perhatian wisatawan asing yang akan berkunjung di Indonesia. Infrastruktur dan aksesibilitas menjadi salah satu yang wajib disediakan oleh pemerintah. Dilihat dari ranking pariwisata dunia, Indonesia berada di ranking 50 masih berada di bawah Thailand, Singapura dan Malaysia. Hal ini menunjukkan kualitas industri pariwisata kita masih perlu diperbaiki, meskipun potensi alam kita lebih baik dibanding dengan negara tetangga. Sehingga diplomasi dalam bidang pariwisata mampu menjadi barometer kesuksesan Indonesia di tingkat Asia Tenggara.

\section{Daftar Pustaka}

ASEAN Tourism Forum (2015). ASEAN Tourism Forum 2015 [online]. ASEAN Tourism Forum. Tersedia di: <http://www.atf-2015.com/ abouttheevent.html> [diakses 14 November 2016].

Gel, I.P. (2006). Industri Pariwisata Indonesia dalam Globalisasi Perdagangan Jasa (GATS-WTO). Bandung: Refika Aditama

Hakim, L. (2010). Industri Pariwisata Dan Pembangunan Nasional [online]. Universitas Hassanudin. Tersedia di: <file://E:/PPIQ\%203/ DOSEN/unhas/industri\%20pariwisata.pdf> [diakses 14 Novem- 
ber 2016].

Hall, C.M. 1994. Tourism and Politics Policy, Power and Place. New York: Wiley.

Kementerian K oordinator Bidang Maritim RI (2009). Undang-Undang Republik Indonesia Nomor 10 Tahun 2009 Tentang Kepariwisataan [online]. Kementerian Koordinator Bidang Maritim RI. Tersedia di: <http://maritim.go.id/wp-content/uploads/2016/01/UU-N o.10-Tahun-2009-Tentang-Kepari wisataan.pdf $>$ diakses 14 November 2016

Kementrian Pariwisata Republik Indonesia (2015). Sambutan Menteri Pariwisata R.I. Pada Peringatan World Tourism Day dan Hari Kepariwisataan Nasional [online]. Kementrian Pariwisata Republik Indonesia. Tersedia dalam <http://www.kemenpar.go.id/asp/detil. asp?c=125\&id=2975> [ diakses 14 November 2016].

Mas'oed, M. (2008). Ekonomi-Politik Internasional dan Pembangunan. Yogyakarta: Pustaka Pelajar.

Nye, J.S. (2004). Soft Power: The Means to Success in World Politics [online]. Belfer Center Harvard University. Tersedia di: <http://belfercenter.ksg.harvard.edu/files/joe_nye_wielding_soft_power.pdf $>$ [diakses 14 November 2016].

Rahmawaty, A. (2015). Kemaritiman Indonesia Problem Dasar Strategi Maritim Indonesia. Surabaya: Cakra Studi Global Strategis (CSGS) Universitas Airlangga dan Intelegensi Media.

Roy, S.L. (1995). Diplomasi. Jakarta: Raja Grafindo Persada.

Tempo (2014). Indonesia Panen Emas di World Folk 2014 Bulgaria [online]. Tempo. Tersedia di: <https://seleb.tempo.co/read/ news/2014/09/01/113603723/indonesia-panen-emas-di-worldfolk-2014-bulgaria> [diakses 14 November 2016].

Tempo (2015). Tarian Indonesia Menarik Minat Mahasiswa Bulgaria [online]. Tempo. Tersedia di: <https://seleb.tempo.co/read/ news/2015/04/21/114659350/tarian-indonesia-menarik-minat-mahasiswa-bulgaria $>$ [diakses 14 November 2016].

UNWTO (2015). Why Tourism [online]. The United Nations World Tourism Organization. Tersedia di: <http://www2.unwto.org/content/ why-tourism> [diakses 14 Novem ber 2016].

Warsito, T. dan Kartikasari, W. (2007). Diplomasi Kebudayaan: Konsep dan Relevansi Bagi Negara Berkembang: Studi Kasus Indonesia. Yogyakarta: O mbak.

WEF. (2016) Index Results - The Travel \& Tourism Competitiveness Index Ranking 2015 [online]. World Economic Forum. Tersedia di: <http://reports. weforum.org/travel-and-tourism-competitiveness-report-2015/ index-results-the-travel-tourism-competitiveness-index-ran- 
king-2015/> [diakses 14 November 2016].

WWF (2015). Pelaku Bisnis Internasional Menjawab Meningkatnya Standar untuk Wisata Bahari yang Berkelanjutan di Kawasan Segitiga Karang [online]. World Wild Life. Tersedia di: <http://www.wwf. or.id/tentang_wwf/upaya_kami/marine/?uNewsID=41343> [diakses 14 November 2016].

Yahya, A. (2015). Pidato Menteri Pariwisata RI Arief Yahya pada Peringatan World Tourism Day dan Hari Kepariwisataan Nasional [online]. Kementerian Pariwisata RI. Tersedia di: <http://www.kemenpar.go.id/asp/detil.as$\mathrm{p} ? \mathrm{c}=125 \& \mathrm{~d}=2975>$ [diakses 14 November 2016].

YFU Indonesia. (2016). Program Year (PY) [online]. Youth for Understanding. Tersedia di: $<$ http://www.yfu.or.id/index.php?option=com_content\&view=article\&id=63\&Itemid $=84>$ [diakses 14 November 2016].

Yudoyono, S.B. (2010). Soft Power Memperkuat Formula Diplomasi [online]. Tabloid Diplomasi. Tersedia di: <www.tabloiddiplomasi.org/pdf/2010/DIPLOMASI\%20Pebruari\%202010.pdf> [diakses 14 Nov ember 2 016]. 